\title{
Substitution of the cysteine 438 residue in the cytoplasmic tail of the glucagon-like peptide- 1 receptor alters signal transduction activity
}

\author{
Patricia Vázquez, Isabel Roncero, Enrique Blázquez \\ and Elvira Alvarez
}

Departamento de Bioquímica y Biología Molecular, Facultad de Medicina, Universidad Complutense de Madrid, Ciudad Universitaria, 28040 Madrid, Spain (Requests for offprints should be addressed to Elvira Alvarez; Email: eao513@med.ucm.es)

\begin{abstract}
Several G-protein-coupled receptors contain cysteine residues in the C-terminal tail that may modulate receptor function. In this work we analysed the substitution of $\mathrm{Cys}^{438}$ by alanine in the glucagon-like peptide-1 (GLP-1) receptor (GLPR), which led to a threefold decrease in cAMP production, although endocytosis and cellular redistribution of GLP-1 receptor agonist-induced processes were unaffected. Additionally, cysteine residues in the C-terminal tail of several G-protein-coupled receptors were found to act as substrates for palmitoylation, which might modify the access of protein kinases to this region. His-tagged GLP-1 receptors incorporated ${ }^{3} \mathrm{H}$-palmitate. Nevertheless, substitution of $\mathrm{Cys}^{438}$ prevented the incorporation of palmitate. Accordingly, we also investigated
\end{abstract}

the effect of substitution of the consensus sequence by protein kinase C (PKC) Ser ${ }^{431 / 432}$ in both wild-type and $\mathrm{Ala}^{438}$ GLP-1 receptors. Substitution of $\mathrm{Ser}^{431 / 432}$ by alanine did not modify the ability of wild-type receptors to stimulate adenylate cyclase or endocytosis and recycling processes. By contrast, the substitution of $\mathrm{Ser}^{431 / 432}$ by alanine in the receptor containing $\mathrm{Ala}^{438}$ increased the ability to stimulate adenylate cyclase. All types of receptors were mainly internalised through coated pits. Thus, cysteine 438 in the cytoplasmic tail of the GLP-1 receptor would regulate its interaction with G-proteins and the stimulation of adenylyl cyclase. Palmitoylation of this residue might control the access of PKC to Ser ${ }^{431 / 432}$.

Journal of Endocrinology (2005) 185, 35-44

\section{Introduction}

Glucagon-like peptide-1(7-36)amide (GLP-1) is an intestinal peptide synthesised in L-cells. It is also produced in the brain (Jin et al. 1988, Kreymann et al. 1989), where it exerts some effects on neurotransmitter release from selected brain nuclei (Mora et al. 1992, Calvo et al. 1995) and produces an inhibitory effect on food and water intake (Navarro et al. 1996, Tang-Christensen 1996, Turton et al. 1996). Subcutaneous administration of GLP-1(736)amide also elicits a reduction in food and water intake (Rodriguez de Fonseca et al. 2000). Similar results were found in human subjects when the peptide was administered peripherally (Gutzwiller et al. 1999). Administered subcutaneously, the peptide could be transported into the brain through the choroid plexus, which has a high density of GLP-1 receptors (GLPR) (Alvarez et al. 1996), or by blood-brain barrier-free organs, such as the subfornical organ and the area postrema (Orskov et al. 1996). It has also been suggested that this peptide acts as a neurotrophic factor. GLP-1 receptors are expressed at high levels in glial cells after mechanical injury (Chowen et al. 1999) and it has recently been shown that GLP-1(7-36)amide can promote the proliferation and differentiation of PC12 cells (Perry et al. 2002).

GLP-1(7-36)amide also has a potent effect on glucosedependent insulin secretion (Kreymann et al. 1987, Weir et al. 1989), and it also increases arterial blood pressure, heart rate (Barragán et al. 1994, 1996), and lung surfactant synthesis (Benito et al. 1998, Vara et al. 2001).

The effects of GLP-1(7-36)amide are mediated through a specific G-protein-coupled receptor (Thorens 1992, Dillon et al. 1993, Wheeler et al. 1993, Wei \& Mojsov 1995, Alvarez et al. 1996) and its signalling on target cells is dependent on activation of the adenylate cyclase pathway (Thorens 1992, Wheeler et al. 1993). In this context, the third intracellular cytoplasmic loop is involved in coupling to $G$ proteins and activation of the adenylyl cyclase system (Takhar et al. 1996). Desensitisation of the GLP-1 receptor has been correlated with C-terminal tail phosphorylation. Homologous desensitisation produced by GLP-1(7-36)amide induces the phosphorylation of three serine doublets located at positions 441/442, 444/445 and $451 / 452$ and decreases maximum cAMP production by 
20\% (Widmann et al. 1997). Heterologous desensitisation of the GLP-1 receptor by protein kinase C (PKC) is correlated with the phosphorylation of four serine doublets located at positions 431/432, 441/442, 444/445 and $451 / 452$. Activation of PKC by phorbol esters also decreases maximum cAMP production by $30 \%$ (Widmann et al. 1996a,b), and the levels of phosphorylation induced by GLP-1 and phorbol esters are additive (Widmann et al. 1996b). Phosphorylation of the three serine doublets, $\mathrm{Ser}^{441 / 442}, \mathrm{Ser}^{444 / 445}$ and $\mathrm{Ser}^{451 / 452}$, at the cytoplasmic tail after agonist binding is related to receptor endocytosis (Widmann et al. 1997). Agonist-promoted phosphorylation of the G-protein-coupled receptors increases the affinity of $\beta$-arrestins and these act as a clathrin adaptor protein in the internalisation process (Goodman et al. 1996).

Most G-protein-coupled receptors have one or two cysteine residues in the carboxyl-terminal cytoplasmic tail, and palmitoylation of these cysteines has been reported for several members of this family of receptors (Bouvier et al. 1995a,b, Morello \& Bouvier 1996). The palmitate tail anchors the cytoplasmic tail of the receptor into the plasma membrane to create a fourth intracellular loop, allowing a reversible and dynamic regulation (Bouvier et al. 1995a).

The aim of this study was to investigate whether cysteine 438 is a site of acylation and the function of $\mathrm{Cys}^{438}$ in signal transduction through GLP-1 receptors.

\section{Materials and Methods}

\section{Mutagenesis of the GLP-1 receptor}

A HindIII-XbaI fragment of the rat GLP-1 receptor cDNA (Thorens 1992) was subcloned into PUC 18. Site-directed mutagenesis of cysteine 438 was accomplished using the Transformer Site-directed Mutagenesis kit from Clontech (Palo Alto, CA, USA). Mutagenic primers were prepared: 5' CCCCTTAAGGCTCCCAC CAGC $3^{\prime}$ to change $\mathrm{Cys}^{438}$ to $\mathrm{Ala}$ and to create a BfrI restriction site, and 5' CCCCTTAAGTGTCCCACC AGC $3^{\prime}$ to create only a BfrI restriction site at nucleotide 1322. A selection primer, 5' GTGTATCTTATGCC AAGTACG $3^{\prime}$, to eliminate a unique NdeI restriction site in the vector was also used. Clones BfrI/ $\mathrm{Ala}^{438}$ and BfrI were selected and mutations were confirmed by sequencing using an automated LKB ALF DNA sequencer (Amersham Pharmacia Biotech, Barcelona, Spain). HindIII-XbaI mutant cDNA was then cloned into the expression vector to create pcDNA3-GLPR $\mathrm{A}^{438}$ and pcDNA3 GLPR BfrI.

For substitution of amino acids $\operatorname{Ser}^{431 / 432}$ by alanine, PCR site-directed mutagenesis was used, following standard procedures. The following primers were used: two flanking primers -GLPR-1 oligonucleotide, corresponding to nucleotides 969-993, and GLPR-2 oligonucleotide, corresponding to nucleotides 1384-1411 (Thorens 1992); the specific mutation primers GLPR-3: 5'CAGAGGGA CGCCGCCATGAAACCCTC3' and GLPR-4: 5'GG TTTCATGGCGGCGTCCCTCTGGATG were employed to mutate $\mathrm{Ser}^{431 / 432}$ into alanine residues. Mutation identity was verified by sequence analysis. The fragments containing the mutated gene were subcloned into the SacI/BfrI restriction sites of pcDNA3-GLPR BfrI and pcDNA3-GLPR $\mathrm{A}^{438}$ to create pcDNA3-GLPR $\mathrm{A}^{431 / 432}$ and pcDNA3-GLPR $\mathrm{A}^{431 / 432 / 438}$.

N-terminal epitope-tagged GLP-1 receptors were constructed by inserting a FLAG epitope (DYKDDDDK) after the initial methionine using a PCR strategy. A HindIII-AlwNI fragment was replaced in wild-type and mutant $\mathrm{A}^{438}$ and designated pcDNA 3 tag-GLPR and pcDNA 3 tag-GLPR $A^{438}$. Also, $6 \times$ His-tagged GLP-1 receptors were constructed. BamHI-XbaI wild-type and mutant cDNAs were subcloned into pcDNA $3 \cdot 1$ /His and designated pcDNA3-His GLPR and pcDNA3-His GLPR $A^{438}$. Wild-type and mutant GLP-1 receptors were expressed in $\mathrm{CHO}$ cells by transfection using the calcium phosphate method. Transfected cells were selected by incubation with neomycin (geneticin, GIBCO). Stable colonies were isolated using cloning rings.

\section{Binding of ${ }^{125}$ I-GLP-1(7-36)amide to cell surface receptors}

GLP-1(7-36)amide was radio-labelled with ${ }^{125}$ I by the chloramine T method and mono ${ }^{125} \mathrm{I}-\mathrm{GLP}-1$ (7-36)amide was isolated by reverse-phase HPLC. Specific activity was between 3500-4000 d.p.m./fmol. CHO cells grown in 24 -well plates $\left(2 \times 10^{5} /\right.$ well $)$ were washed with serumfree medium and incubated for $30 \mathrm{~min}$ at $37^{\circ} \mathrm{C}$ in $\mathrm{KRH}$ $\left(118 \mathrm{mM} \mathrm{NaCl}, 5 \mathrm{mM} \mathrm{KCl}, 1 \cdot 2 \mathrm{mM} \mathrm{MgSO}_{4}, 2.5 \mathrm{mM}\right.$ $\mathrm{CaCl}_{2}, 25 \mathrm{mM}$ HEPES, $\mathrm{pH} 7 \cdot 4$ ) with $0.5 \%$ bovine serum albumin (BSA). Then, cells were chilled on ice, and ${ }^{125}$ I-GLP-1(7-36)amide $(0 \cdot 1 \mathrm{nM})$ and unlabelled GLP1(7-36)amide $(0 \cdot 0-500 \mathrm{nM})$ were added for at least $16 \mathrm{~h}$ at $4{ }^{\circ} \mathrm{C}$. Following this, cells were washed three times with cold medium and solubilised with $1 \mathrm{M} \mathrm{NaOH}$. Nonspecific binding of ${ }^{125} \mathrm{I}-\mathrm{GLP}-1(7-36)$ amide was estimated in the presence of $500 \mathrm{nM}$ unlabelled ligand and this value was subtracted from the total binding values.

\section{cAMP production assays}

cAMP levels were measured using the cAMP Biotrack enzyme immunoassay system (Amersham Biosciences, UK) following the manufacturer's instructions. Briefly, untransfected $\mathrm{CHO}$ cells and cells expressing wild-type and mutant GLP-1 receptors were grown in 12-well plates in F-12 medium supplemented with 5\% FBS. CHO cells were washed and incubated in F-12 medium containing $0 \cdot 1 \%$ FBS overnight. Cells were then washed with HBS medium $\left(130 \mathrm{mM} \mathrm{NaCl}, 0.9 \mathrm{mM} \mathrm{NaH} \mathrm{PO}_{4}, 0.8 \mathrm{mM}\right.$ $\mathrm{MgSO}_{4}, 5 \cdot 4 \mathrm{mM} \mathrm{KCl}, 1 \cdot 8 \mathrm{mM} \mathrm{CaCl} 2,20 \mathrm{mM}$ HEPES, $\mathrm{pH} 7 \cdot 4$, plus $25 \mathrm{mM}$ glucose) and incubated in HBS 
containing $1 \mathrm{mM}$ IBMX and $0 \cdot 1 \% \mathrm{BSA}$ in the presence or absence of different concentrations of GLP-1(7-36)amide (0.001-100 nM) for $8 \mathrm{~min}$. Then, cells were washed with HBS, after which lysis buffer was added and immediately processed in the immunoassay. In parallel experiments, binding of ${ }^{125}$ I-GLP-1(7-36)amide to cell surface receptors was determined at $4{ }^{\circ} \mathrm{C}$. The agonist stimulated cAMP production was normalised by ${ }^{125} \mathrm{I}-\mathrm{GLP}-1(7-36)$ amide bound to cell surface receptors.

\section{Internalisation of the GLP-1 receptor}

The internalisation rate was measured as previously described (Alvarez et al. 1990). Briefly, CHO cells were incubated in $\mathrm{KRH}(118 \mathrm{mM} \mathrm{NaCl}, 5 \mathrm{mM} \mathrm{KCl}, 1 \cdot 2 \mathrm{mM}$ $\mathrm{MgSO}_{4}, 2.5 \mathrm{mM} \mathrm{CaCl}, 25 \mathrm{mM}$ HEPES, $\left.\mathrm{pH} 7 \cdot 4\right)$ with $0.5 \% \mathrm{BSA}$ at $37^{\circ} \mathrm{C}$ for $30 \mathrm{~min}$. Then, cells were incubated with $0 \cdot 1 \mathrm{nM}{ }^{125} \mathrm{I}-\mathrm{GLP}-1(7-36)$ amide, and ${ }^{125} \mathrm{I}-\mathrm{GLP}-1$ (736)amide binding was determined at different times. Intracellular ${ }^{125}$ I-GLP-1(7-36)amide was measured as cell-associated radioactivity resistant to acid wash by incubation of the cells for $3 \mathrm{~min}$ at $4{ }^{\circ} \mathrm{C}$ with $50 \mathrm{mM} \mathrm{NaCl}$, $150 \mathrm{mM}$ glycine, $\mathrm{pH} 3 \cdot 0$. Cell surface-bound ${ }^{125} \mathrm{I}-\mathrm{GLP}-$ 1(7-36)amide was calculated by subtraction of the intracellularly bound ${ }^{125}$ I-GLP-1(7-36)amide from the total binding.

\section{Effect of metabolic inhibitors and hypertonic medium on the internalisation process}

For metabolic depletion, $\mathrm{CHO}$ cells were washed twice with glucose-free HBS $(140 \mathrm{mM} \mathrm{NaCl}, 20 \mathrm{mM}$ HEPES, $1 \mathrm{mM} \mathrm{CaCl}, 1 \mathrm{mM} \mathrm{MgCl}, 10 \mathrm{mM} \mathrm{KCl}$ with $0 \cdot 5 \%$ BSA) and incubated in the same buffer containing $20 \mathrm{mM}$ 2-deoxyglucose and $10 \mathrm{mM}$ sodium azide. Hypertonic treatment was performed as previously described (Heuser \& Anderson 1989). Briefly, cells were washed twice with HBS containing $0.45 \mathrm{M}$ sucrose and incubated in the same medium for $30 \mathrm{~min}$ at $37{ }^{\circ} \mathrm{C}$. Then, $0 \cdot 1 \mathrm{nM}{ }^{125} \mathrm{I}-\mathrm{GLP}-$ 1(7-36)amide was added and after $6 \mathrm{~min}$ incubation cell-associated radioactivity and acid wash-resistant radioactivity were measured as previously described.

\section{Redistribution of cell surface GLP-1 receptors}

$\mathrm{CHO}$ cells were seeded in 24-well plates and incubated with $10 \mathrm{nM}$ GLP-1(7-36)amide for different times (3, 6, $10,15,30$ and $60 \mathrm{~min})$. Then, the cells were washed at $0{ }^{\circ} \mathrm{C}$ and subsequently incubated for $3 \mathrm{~min}$ at $0{ }^{\circ} \mathrm{C}$ with $50 \mathrm{mM} \mathrm{NaCl}, 150 \mathrm{mM}$ glycine, $\mathrm{pH} 3 \cdot 0$, to remove ligand bound to the cell surface, and washed with $\mathrm{KRH}$ containing $0.5 \%$ BSA. Cell surface receptors were then measured as described above.

\section{Immunoprecipitation of tag-GLPR receptors}

$\mathrm{CHO}$ cells expressing tag-GLPR wild-type or mutant receptors were seeded in $60 \mathrm{~cm}^{2}$ dishes for metabolic labelling. The cells were transferred into culture media: (1) methionine-free modified Eagle's medium containing $150 \mu \mathrm{Ci} / \mathrm{ml}^{35} \mathrm{~S}$-methionine (Amersham Pharmacia Biotech) and (2) F-12 medium containing 1\% fetal bovine serum (FBS) (GIBCO, Life Technologies, Paisley, UK) and $200 \mu \mathrm{Ci} / \mathrm{ml}^{3} \mathrm{H}$-palmitate (Dupont-NEN, Boston, MA, USA). The cells were then washed and solubilised in PBS containing 1\% Triton X-100, 1\% deoxycholate, $0 \cdot 1 \%$ SDS, $0.5 \mathrm{M} \mathrm{NaCl}, 5 \mathrm{mM}$ EDTA, $1 \mathrm{mM}$ PMSF, $50 \mathrm{mM}$ $\mathrm{NaF}, 5 \mathrm{mM} \mathrm{Na}{ }_{4} \mathrm{P}_{2} \mathrm{O}_{7}$ and $1 \mathrm{mM} \mathrm{Na} \mathrm{VO}_{4}$. The lysates were centrifuged at $10000 \mathrm{~g}$ for $30 \mathrm{~min}$ and the supernatants were incubated with agarose-Streptavidin at room temperature for $30 \mathrm{~min}$. After centrifugation, the supernatants were incubated for $60 \mathrm{~min}$ at room temperature with monoclonal anti-FLAG epitope M2-biotin conjugate antibody (SIGMA, Madrid, Spain) prebound to $50 \mu \mathrm{l}$ agarose-Streptavidin or monoclonal anti-FLAG epitope M2-agarose (SIGMA). The immunoprecipitates were washed and resolved by SDS-PAGE and fluorography.

For purification of His-tagged GLP-1 receptors, crude membrane fractions of $\mathrm{CHO}$ cells expressing GLP-1 receptors were loaded into His micro spin columns (Amersham Biosciences Europe, Barcelona, Spain) previously incubated in the presence or absence of an excess of polyHis $(30 \mu \mathrm{g} / \mathrm{ml})$. Then, the columns were washed twice with phosphate/ $\mathrm{NaCl}$ solution containing $20 \mathrm{mM}$ imidazole and twice with phosphate $/ \mathrm{NaCl} 60 \mathrm{mM}$ imidazole and finally eluted with phosphate $/ \mathrm{NaCl}$ solution containing $400 \mathrm{mM}$ imidazole. Western blot analyses with anti-His antibody (Amersham Biosciences Europe) were performed following the manufacturer's instructions.

CHO cells expressing His-wild-type or mutant GLP-1 receptors were also labelled with ${ }^{35} \mathrm{~S}$-methionine or ${ }^{3} \mathrm{H}$ palmitate as described above. His-tagged GLP-1 receptors were purified using His micro spin columns and samples were resolved by SDS-PAGE and fluorography.

\section{Data analysis}

Data from competition experiments were analysed by non-linear regression with the GraphPad Prism computer program (GraphPad Software Inc., San Diego, CA, USA). Dissociation constants $\left(K_{d}\right)$ and concentrations of receptor sites $\left(\mathrm{B}_{\max }\right)$ were calculated from $\mathrm{IC}_{50}$ values using the method of Cheng and Prusoff (1973). Data are expressed as means \pm S.E.M. Statistical comparisons were performed using the Student's $t$-test and Newman-Keuls test with at least three separate experiments performed in duplicate $\left({ }^{*} P<0 \cdot 05\right.$ and $\left.* * P<0 \cdot 001\right)$.

\section{Results}

Effect of the mutation in Cys ${ }^{438}$ on GLP-1 receptor binding To analyse the role of $\mathrm{Cys}^{438}$ located in the C-terminal domain of the GLP-1 receptor (Fig. 1), we constructed a 


\section{PRIMARY STRUCTURE}

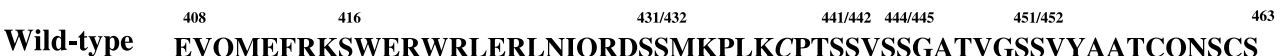

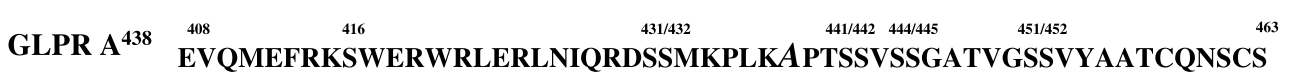

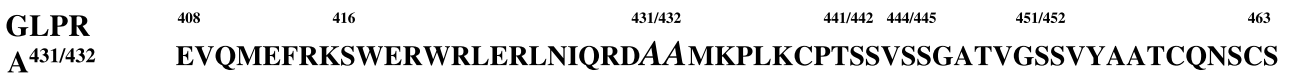

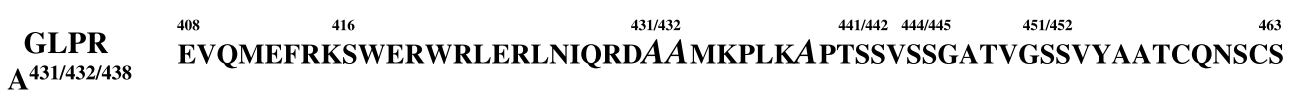

Figure 1 Amino acid sequence of the C-terminal tail of the wild-type and GLP-1 receptor mutants. The 56 C-terminal amino acids of the rat wild-type and mutant GLP-1 receptor are shown. Italicised letters represent substituted or mutated residues.

series of mutant receptors in which $\mathrm{Cys}^{438}$ or $\mathrm{Ser}^{431,432}$ were substituted by alanine (Fig. 1). CHO cells expressing wild-type or mutant receptors (GLPR $\mathrm{A}^{438}$, GLPR $\mathrm{A}^{431 / 432}$ and GLPR $\mathrm{A}^{431 / 432 / 438}$ ) were used to determine the binding properties of ${ }^{125}$ I-GLP-1(7-36)amide to all receptors. The competition binding curves are shown in Fig. 2. The $K_{\mathrm{d}}$ and $\mathrm{B}_{\max }$ calculated from the $\mathrm{IC}_{50}$ values are shown in Table 1 . The competition binding data of wild-type and mutant receptors fit a single-site model best.

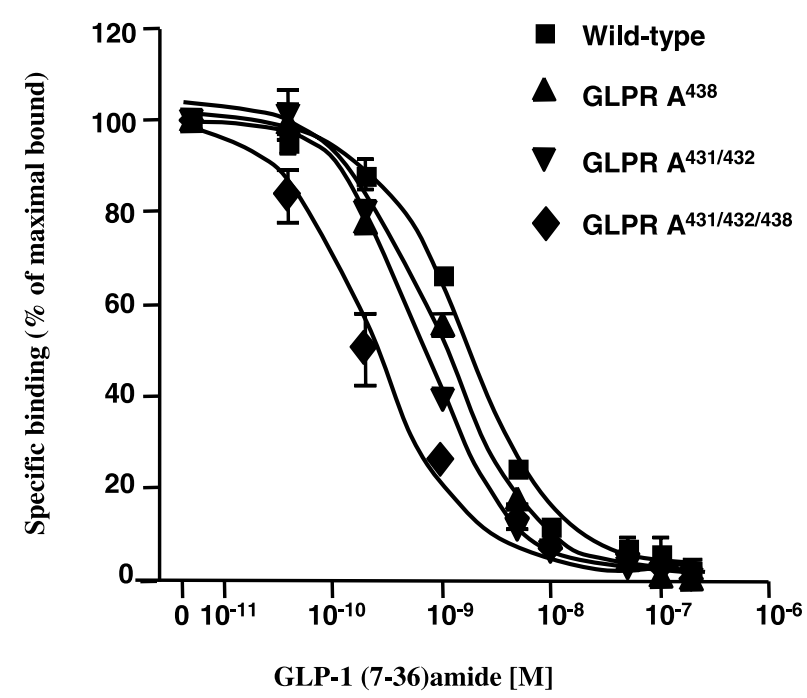

Figure 2 Analysis of ${ }^{125}$ I-GLP-1(7-36)amide binding to wild-type and mutant GLP-1 receptors. CHO cells expressing wild-type, GLPR A ${ }^{438}$, GLPR $A^{431 / 432}$ and GLPR A $A^{431 / 432 / 438}$ GLP-1 receptors were incubated with $0 \cdot 1 \mathrm{nM}{ }^{125}$ I-GLP-1(7-36)amide and increasing concentrations of the unlabelled peptide. The competition binding curves are shown. Data are means \pm S.E.M. $(n=3-6)$ and are expressed as a percentage of maximal specific binding.
Activation of adenylate cyclase

The binding of GLP-1(7-36)amide to its receptor produces activation of the adenylate cyclase pathway. Accordingly, we tested the effect of this peptide on the production of cAMP by cells transfected with the wildtype and mutant GLP-1 receptors. As shown in Fig. 3, GLP-1(7-36)amide stimulated $\mathrm{CHO}$ cells expressing wild-type receptors in a dose-dependent manner; the $\mathrm{EC}_{50}$ of GLP-1(7-36) amide was 0.09 $\pm 0.03 \mathrm{nM}$, maximum stimulation $\left(R_{\max }\right)$ being observed at $10 \mathrm{nM}$ of the agonist (Table 1). CHO cells expressing mutant GLPR $\mathrm{A}^{438}$ receptors showed a similar $\mathrm{EC}_{50} 0 \cdot 05 \pm 0 \cdot 016 \mathrm{nM}$ value calculated from the dose-response curve (Fig. 3). However, the mutant receptor revealed a $60-70 \%$ decreased efficacy as compared with wild-type receptors (Table 1). Similar results were obtained using a pool of clones expressing the wild-type and mutant GLP-1 receptors.

\section{Post-translational modifications of the GLP-1 receptor}

To investigate post-translational modifications of the GLP-1 receptor by acylation, CHO cells expressing tagwild-type GLP-1 receptors were labelled with ${ }^{35} \mathrm{~S}-$ methionine and ${ }^{3} \mathrm{H}$-palmitic acid. The immunoprecipitates were analysed by non-reducing polyacrylamide gel electrophoresis and fluorography. The epitope-tagged GLP-1 receptors were not immunoprecipitated by antiFLAG M2 monoclonal antibody or anti-FLAG M2 affinity gel, and hence we could not detect tag-GLP-1 receptors in cells labelled with ${ }^{35} \mathrm{~S}$-methionine. We therefore decided to use $6 \times$ His-tagged GLP-1 receptors. His-GLP-1 receptors were isolated using His micro spin columns. Western blot analysis using an anti-His antibody (Fig. 4) revealed the presence of a $65 \mathrm{kDa}$ band in $\mathrm{CHO}$ cells expressing His-tagged wild-type and mutant $\mathrm{Ala}^{438}$ 
Table 1 GLP-1(7-36)amide binding parameters and adenylyl cyclase stimulation for wild-type and mutant GLP-1 receptors expressed in $\mathrm{CHO}$ cells. The GLP-1(7-36)amide binding parameters were determined by competitive binding assays using $\mathrm{CHO}$ cells stably transfected with wild-type and mutant GLP-1 receptors. The data were analysed by non-linear regression and the dissociation constant $\left(\mathrm{K}_{\mathrm{d}}\right)$ and the concentration of receptor sites $\left(B_{\max }\right)$ of these receptors were calculated from $I C_{50}$ values as described in Materials and Methods. The data of adenylyl cyclase activity were analysed using non-linear least squares regression. The agonist potency $\mathrm{EC}_{50}$ and maximal GLP-1(7-36)amide-stimulated adenylyl cyclase activity $\left(R_{\max }\right)$ are shown. The data represent the mean \pm S.E.M. of three to six independent experiments

\section{${ }^{125}$ I-GLP-1(7-36)amide binding parameters}

$K_{\mathrm{d}}(\mathrm{nM})$

\section{Receptor}

Wild-type

GLPR A $A^{438}$

GLPR A $A^{431 / 432}$

GLPR A A31/432/438 $^{4}$
$1 \cdot 46 \pm 0 \cdot 08$

$0 \cdot 905 \pm 0 \cdot 15$

$0 \cdot 515 \pm 0 \cdot 03$

$0 \cdot 44 \pm 0 \cdot 22$
$B_{\max }\left(\mathrm{fmol} / 2 \times 10^{5}\right.$ cells $)$

$12 \pm 1 \cdot 65$

$42 \cdot 22 \pm 6 \cdot 41$

$30 \cdot 05 \pm 2 \cdot 56$

$1 \cdot 12 \pm 0 \cdot 4$
Adenylyl cyclase stimulation

\begin{tabular}{|c|c|}
\hline $\mathrm{EC}_{50}(\mathrm{nM})$ & $R_{\max }\left(\mathrm{pmol} / 2 \times 10^{5}\right.$ cells $)$ \\
\hline $0.09 \pm 0.03$ & $7 \cdot 4 \pm 1 \cdot 5$ \\
\hline $0 \cdot 05 \pm 0.016$ & $2 \cdot 6 \pm 0 \cdot 6$ \\
\hline $0.06 \pm 0.02$ & $6 \cdot 6 \pm 0 \cdot 14$ \\
\hline $0 \cdot 44 \pm 0 \cdot 22$ & $28 \cdot 5 \pm 5 \cdot 7$ \\
\hline
\end{tabular}

GLP-1 receptors. This band disappeared when the columns were previously saturated with polyHis. $\mathrm{CHO}$ cells expressing His-tagged wild-type and mutant GLP-1 receptors were metabolically labelled with ${ }^{35} \mathrm{~S}$-methionine and ${ }^{3} \mathrm{H}$-palmitate. His-GLP-1 receptors were purified with His micro spin columns and subjected to SDS-PAGE and fluorography. As shown in Fig. 4, when the cells were labelled with ${ }^{35} \mathrm{~S}$-methionine a $65 \mathrm{kDa}$ band was detected in cells transfected with wild-type and mutant GLPR A ${ }^{438}$ receptors. However, when the cells were labelled with ${ }^{3} \mathrm{H}$-palmitate, the incorporation of ${ }^{3} \mathrm{H}$-palmitate was only

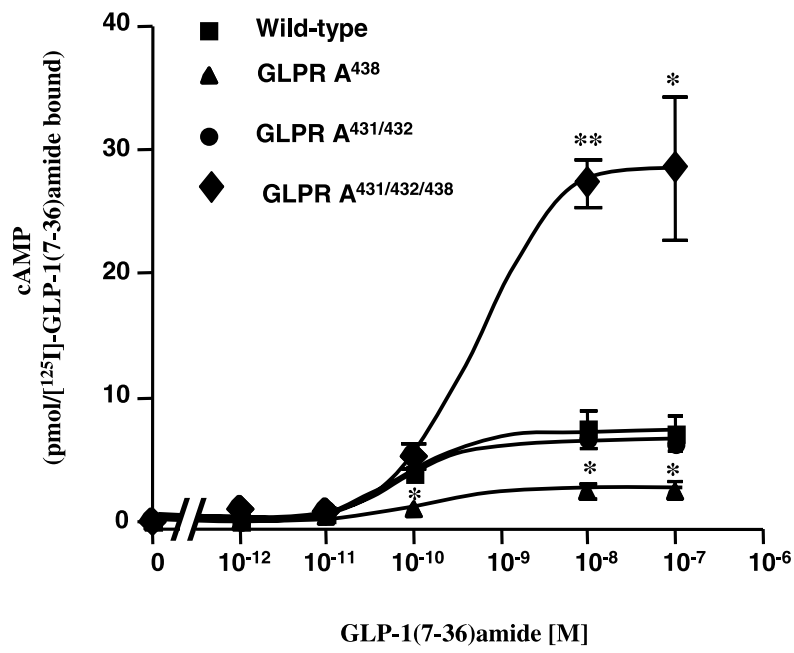

Figure 3 Effect of GLP-1(7-36)amide on CAMP production by $\mathrm{CHO}$ cells transfected with wild-type and GLPR $\mathrm{A}^{438}$, GLPR $\mathrm{A}^{431 / 432}$ and GLPR A $\mathrm{A}^{431 / 432 / 438}$ GLP-1 receptors. CHO cells expressing wild-type and mutant GLP-1 receptors were stimulated with different concentrations (0.001-100 nM) of GLP-1(7-36)amide for 8 min and CAMP production was determined by enzyme immunoassay and normalised by ${ }^{125}$ I-GLP-1(7-36)amide bound to cell surface receptors. The data presented are means \pm S.E.M. of three to six separate experiments performed in duplicate. ${ }^{*} P<0 \cdot 05,{ }^{* *} P<0 \cdot 001$, compared with cells expressing wild-type receptors (Neuman-Keuls test). observed in cells expressing wild-type receptors. No ${ }^{3} \mathrm{H}$-palmitate-labelled band was detected in samples purified from CHO-K1 and mutant GLPR A ${ }^{438}$ receptorexpressing cell lines, although the expression levels of the wild-type and mutant GLPR A ${ }^{438}$ receptors were similar in this experiment, as indicated by the ${ }^{35}$ S-labelled purification. These data are consistent with the hypothesis that $\mathrm{Cys}^{438}$ is a site of GLP-1 receptor palmitoylation.

The presence of cysteine residues in many G-proteincoupled receptors allows post-translational modification by palmitoylation. It has also been demonstrated that the palmitic acid tail can attach the cytoplasmic domain of the receptor to the cell membrane, which should change accessibility to the phosphorylation sites closest to Cys ${ }^{438}$ $\left(\mathrm{Ser}^{431,432}\right.$ and $\left.\mathrm{Ser}^{441,442}\right)$. In other experiments we used a receptor lacking Ser ${ }^{431,432}$, the consensus phosphorylation site for PKC (GLPR A ${ }^{431 / 432 / 438}$ ), but keeping the three serine doublets 441/442, 444/445 and 451/452, identified as the sites of homologous phosphorylation in response to agonist binding. To check the specific effect of substitution of Ser ${ }^{431,432}$ by alanine a mutant GLPR A A31/432 $^{\text {was }}$ also used (Fig. 1).

Effect of substitution of Ser ${ }^{431 / 432}$ by alanine on adenylate cyclase activation

Substitution of Ser ${ }^{431 / 432}$ by alanine in the wild-type receptor did not modify the potency and efficacy of such receptors in stimulating cAMP production (Fig. 3, Table 1). By contrast, in cells expressing GLPR A ${ }^{431 / 432 / 438}$ the $\mathrm{EC}_{50}$ value of GLP-1(7-36)amide was similar to that of the wild-type, but the efficacy was three- to fourfold increased relative to the wild-type (Table 1).

Effect of the Cys ${ }^{438}$ mutation and the substitution of
Ser 4311432 by alanine on the rate of GLP-1 receptor
endocytosis

Figure 5A shows that the substitution of $\mathrm{Cys}^{438}$ or Ser ${ }^{431 / 432}$ by alanine in the GLP-1 receptor did not 
A
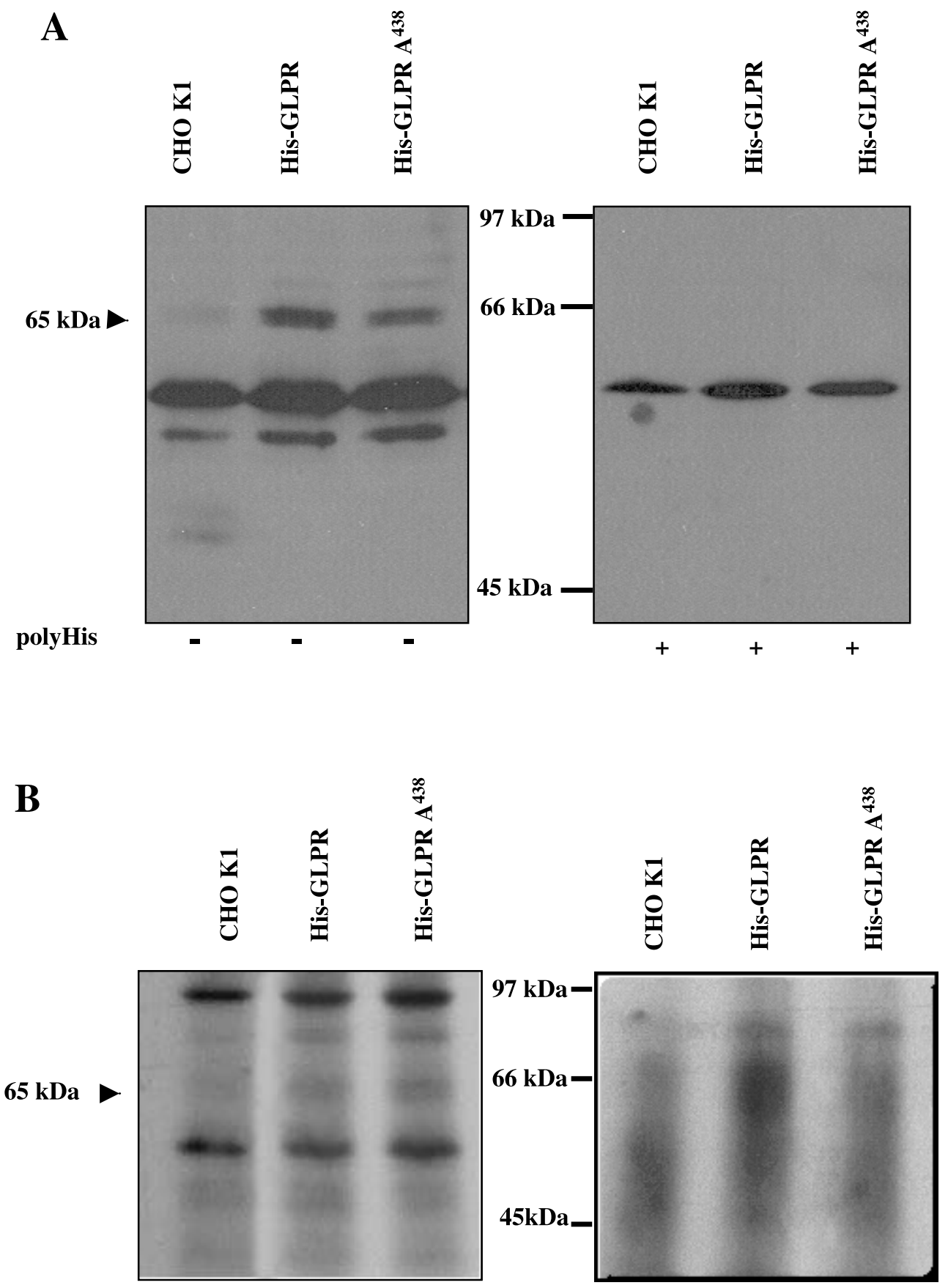

$\left[{ }^{35}\right.$ S]-Methionine

$\left[{ }^{3} \mathbf{H}\right]$-Palmitate

Figure 4 Immunological detection of His-GLP-1 receptors and fluorography. (A) Eluates of the His micro spin column previously incubated with $(+)$ or without $(-)$ excess polyHis were processed by SDS-PAGE and Western blot. An immunoblot using an anti-His antibody is shown. Arrows indicate the positions of immunoreactive proteins. (B) $\mathrm{CHO}$ cells expressing His-GLPR and His-GLPR A ${ }^{438}$ receptors were labelled with ${ }^{35} \mathrm{~S}$-methionine and ${ }^{3} \mathrm{H}$-palmitate. His-GLP-1 receptors were purified with His micro spin columns and resolved by SDS-PAGE and fluorography. The figure presents an autoradiograph of the dried gel. 
modify the rate of its internalisation. The first-order endocytic rates measured for wild-type, GLPR $A^{438}$, GLPR $\mathrm{A}^{431 / 432}$ and GLPR $\mathrm{A}^{431 / 432 / 438}$ were $0 \cdot 198 \pm 0 \cdot 005 \mathrm{~min}^{-1}, \quad 0 \cdot 217 \pm 0 \cdot 006 \mathrm{~min}^{-1}, \quad 0 \cdot 18 \pm$ $0 \cdot 014 \mathrm{~min}^{-1}$ and $0 \cdot 22 \pm 0 \cdot 015 \mathrm{~min}^{-1}$ respectively. The rate of endocytosis of GLP-1 receptors was also similar in a pool of clones expressing the wild-type and mutant GLP-1 receptors. The effects of metabolic inhibitors or hypertonic medium on the rate of endocytosis were also measured (Fig. 5B). The rate of endocytosis was inhibited by 73-90\% under both conditions after metabolic depletion and hypertonic treatment in cells expressing wild-type or mutant receptors.

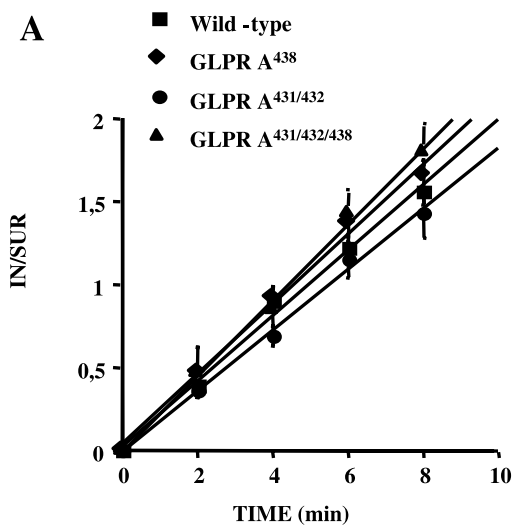

B
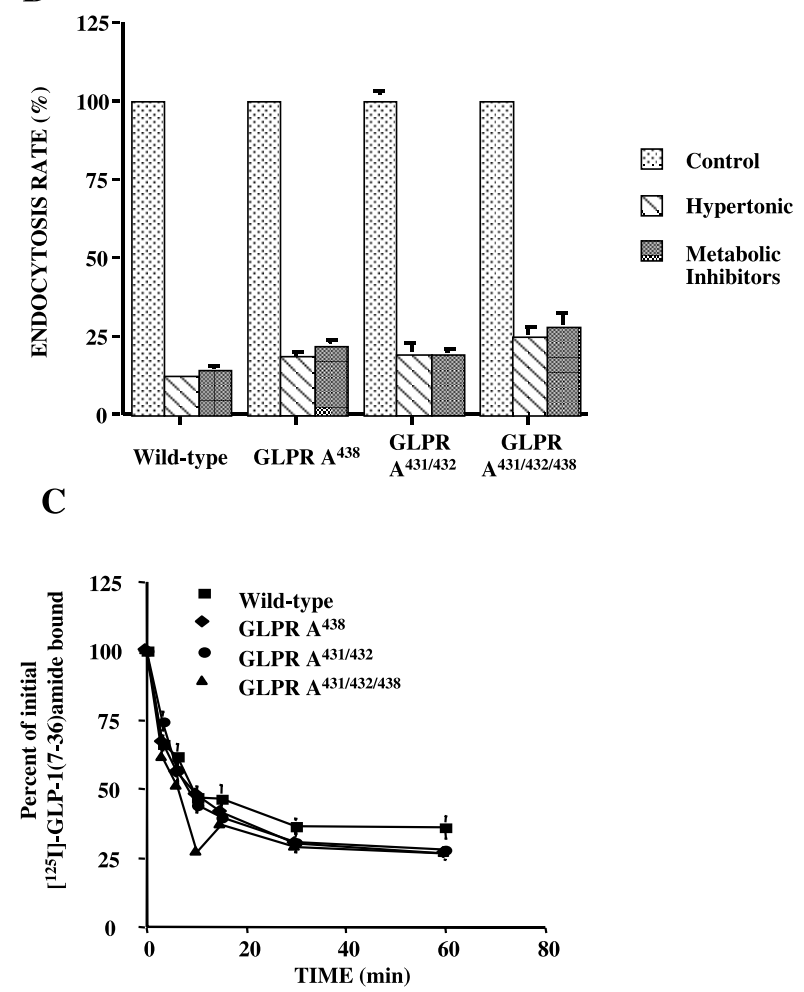

www.endocrinology-journals.org
Effect of agonist on the cellular redistribution of GLP-1 receptors

It has been reported that GLP-1 receptor recycling to the cell surface following agonist-induced endocytosis takes about $15 \mathrm{~min}$ and that a rapid rate of endocytosis produces a progressive decrease in the surface expression of GLP-1 receptors upon continuous exposure to the agonist.

The effect of pre-exposure to $10 \mathrm{nM}$ GLP-1(736)amide on cell surface receptors was determined as a function of time, as shown in Fig. 5C. A rapid decrease in cell surface receptor numbers was observed in cells expressing wild-type and mutant GLP-1 receptors. In both cases, the number of cell surface receptors decreased during the first $15 \mathrm{~min}$ of agonist exposure, receptor numbers falling to $45-50 \%$ of the initial values. After longer times of exposure, the number of cell surface receptors decreased slowly to $36-27 \%$ in cells expressing wild-type and mutant receptors respectively.

\section{Discussion}

Here we report the results obtained following the replacement of $\mathrm{Cys}^{438}$ by alanine in the rat GLP-1 receptor.

The data obtained by us show that the GLP-1 receptor is palmitoylated and that substitution of $\mathrm{Cys}^{438}$ by alanine prevented ${ }^{3} \mathrm{H}$-palmitate incorporation to GLP-1 receptors. We do not have any information about the stoichiometry of GLP-1 receptor palmitoylation.

As compared with the wild-type receptor, the efficacy of mutant $\mathrm{A}^{438}$ receptors in stimulating adenylate cyclase activity after GLP-1(7-36)amide treatment decreased approximately threefold. A decrease in cAMP production in cells expressing mutant GLPR A ${ }^{438}$ receptors is consistent

Figure 5 Agonist-induced endocytosis and redistribution of GLP-1 receptors and the effect of metabolic inhibitors and hypertonic medium on endocytosis in cells expressing wild-type and mutant GLP-1 receptors. (A) The rate of ${ }^{125}$ I-GLP-1(7-36)amide endocytosis was measured in $\mathrm{CHO}$ cells expressing wild-type, GLPR A ${ }^{438}$, GLPR A ${ }^{431 / 432}$ and GLPR A ${ }^{431 / 432 / 438}$ GLP-1 receptors. Cells were incubated with $0 \cdot 1 \mathrm{nM}$

${ }^{125}$ I-GLP-1(7-36)amide. After defined times, total and acid wash-resistant (intracellular) cell-associated radioactivity was measured. Data are represented in the form of an IN/SUR plot, means \pm S.E.M. $(n=6)$. IN, intracellular ${ }^{125}$ I-GLP-1(7-36)amide; SUR, cell surface-bound ${ }^{125}$ I-GLP-1(7-36)amide. (B) The effects of metabolic depletion and hypertonic medium in the internalisation process were analysed in $\mathrm{CHO}$ cells expressing wild-type or mutant GLP-1 receptors. The data are percentages of the rate of endocytosis and are means \pm S.E.M. of three independent experiments performed in triplicate. (C) The effect of pretreatment with $10 \mathrm{nM}$ GLP-1(7-36)amide on cell surface expression of GLP-1 receptors was investigated. Cells were incubated in the presence of agonist for different times, after which the cells were washed and the ligand bound to the cell surface was removed by acid washing. Finally, ${ }^{125}$ I-GLP-1(7-36)amide binding to cell surface receptors was measured. Results are means \pm S.E.M. $(n=6)$. 
with the data reported for non-palmitoylated $\beta_{2}$ adrenergic receptors (O'Dowd et al. 1989) and the D1 dopamine receptor (Jensen et al. 1995). In our data, the differences in cAMP production are not correlated with a change in the agonist-affinity state of GLP-1 receptors after the substitution of $\mathrm{Cys}^{438}$ by alanine.

Replacement of Cys ${ }^{438}$ or substitution of $\mathrm{Ser}^{431 / 432}$ did not affect the processing of mutant receptors. Under these experimental conditions, wild-type and mutant receptors showed a similar agonist binding affinity. In contrast, the expression level of mutant $A^{438}$ and $A^{431 / 432}$ at the cell surface was higher than for wild-type GLP-1 receptors, and $\mathrm{CHO}$ cells transfected with mutant $\mathrm{A}^{431 / 432 / 438}$ expressed low levels of receptors as compared with wildtype receptors. Thus, these findings cannot be related to the effect of palmitoylation or depalmitoylation.

It has been reported that the region involved in the coupling of GLP-1 receptors to G proteins is located in the third intracellular cytoplasmic loop (Takhar et al. 1996) and that C-terminal tail phosphorylation is involved in the desensitisation process. Nevertheless, a receptor lacking 33 amino acids of the C-terminal tail stimulates cAMP production at the same rate as wild-type receptors (Widmann et al. 1996a,b). We also tested a truncated receptor lacking 27 amino acids of the C-terminal tail and this truncated form stimulated cAMP production at a similar rate to wild-type receptors, indicating that this region of the cytoplasmic tail is not necessary for the GLP-1 receptor/G protein interaction (our unpublished data).

Palmitoylation of cysteines in the carboxyl terminal tail of G-protein-coupled receptors anchors this receptor domain into the plasma membrane, forming a fourth intracellular loop. Substitution of Cys ${ }^{438}$ in GLP-1 receptors abolishes ${ }^{3} \mathrm{H}$-palmitate incorporation, which should produce a different conformational state of the carboxyl terminal tail and may affect the access of kinases to the cytoplasmic tail.

The cytoplasmic tail of GLPR also contains several phosphorylation sites reported to be necessary for the internalisation and desensitisation of GLP-1 receptors. Previous work using GLP-1 receptors revealed that PKC activation by phorbol esters produced phosphorylation of the four serine doublets in the intracytoplasmic tail: $\mathrm{Ser}^{431 / 432}, \operatorname{Ser}^{441 / 442}, \mathrm{Ser}^{444 / 445}$ and $\mathrm{Ser}^{451 / 452}$ (Widmann et al. 1996a). Agonist binding to the GLP-1 receptor also induces phosphorylation of three doublets: $\operatorname{Ser}^{441 / 442}$, Ser ${ }^{444 / 445}$ and Ser ${ }^{451 / 452}$ (Widmann et al. 1997), and the receptor phosphorylation induced by homologous and heterologous desensitisation is additive (Widmann et al. 1996b). The substitution of Cys ${ }^{438}$ might regulate the access of protein kinases to such phosphorylation sites. Thus, the phosphorylation of a protein kinase A (PKA) site in the $\beta_{2}$-adrenergic receptor located downstream from the palmitoylated cysteine is also dependent on the state of palmitoylation of the receptor (Moffett et al. 1993,
1996). It has also been reported that mutations of the two Cys residues in the $\mathrm{A}^{3}$-adenosine receptor increase phosphorylation of the receptor independently of the presence of agonist (Palmer \& Stiles 2000). Palmitoylation of the vasopressin $\mathrm{V}_{1 \mathrm{a}}$ receptor also regulates phosphorylation, but in this case the reduction of $\left[{ }^{3} \mathrm{H}\right]$ palmitate incorporation decreased the basal level of phosphorylation of mutant receptors (Hawtin et al. 2001).

Since our data indicated that the rate of endocytosis was similar in wild-type and mutant receptors, and since it has been reported that phosphorylation of the three doublets $\mathrm{Ser}^{441 / 442}, \operatorname{Ser}^{444 / 445}$ and Ser ${ }^{451 / 452}$ is involved in this process, we next investigated the effect of the substitution of serines $431 / 432$ by alanines in the wild-type and GLPR $\mathrm{A}^{438}$ receptors. The substitution of $\mathrm{Ser}^{431 / 432}$ by alanine did not modify the potency or efficacy of these receptors in stimulating adenylate cyclase. In contrast, substitution of these residues in GLPR $A^{438}$ receptors increased the efficacy in stimulating adenylate cyclase at concentrations higher than $1 \mathrm{nM}$ GLP-1(7-36)amide.

The results obtained after the substitution of Ser ${ }^{431 / 432}$ by alanine when $\mathrm{Cys}^{438}$ is also absent suggest that the rate of phosphorylation of the other serine doublets in the cytoplasmic tail might also be affected. To confirm this hypothesis it would be necessary to analyse the effect of substitution of the other sites of phosphorylation involved in the desensitisation and internalisation of GLP-1 receptors. However, a synergistic action of kinases on other members of G-protein-coupled receptors, such as $\beta_{2^{-}}$ adrenergic receptors (Moffett et al. 2001) and $A_{3}$ adenosine receptors (Palmer \& Stiles 2000), has been reported previously.

The effect of the substitution of Cys ${ }^{438}$ by alanine on the endocytosis and recycling processes was also tested. The GLPR $A^{438}$ receptors did not show significant differences in the internalisation rate as compared with the wild-type GLP-1 receptor and, likewise, the number of cell surface receptors after agonist exposure decreased in the same way as in cells expressing the wild-type receptors. Substitution of $\mathrm{Ser}^{431 / 432}$ by alanine in wild-type and GLPR $A^{438}$ did not modify either the rate of endocytosis or the number of cell surface receptors after exposure to $10 \mathrm{nM}$ agonist. The effect of acid washing was similar in all clones used. Our results suggest that the substitution of $\mathrm{Ser}^{431 / 432}$ or $\mathrm{Cys}^{438}$ by Ala in the GLP-1 receptor does not modify the capacity of these receptors to interact with the components of the vesicular transport system.

We also studied the endocytosis pathway used by these receptors, testing the effect of hypertonic medium; we found that all wild-type and mutant GLPR $A^{438}$, GLPR $A^{431 / 432}$ and GLPR $A^{431 / 432 / 438}$ receptors were mainly internalised through coated pits.

In conclusion, the substitution of $\mathrm{Cys}^{438}$ in the cytoplasmic tail of GLP-1 receptors decreases the efficacy of adenylate cyclase stimulation promoted by agonist binding through these receptors. In addition, this residue is a site of 
acylation of GLP-1 receptors and might regulate the state of phosphorylation of the GLP-1 receptor, which modulates the desensitisation process. Nevertheless, further studies are required to confirm the latter hypothesis.

\section{Acknowledgements}

This study was supported by grants from Dirección General de Investigación Científica y Técnica (DGICYT), Fondo de Investigación Sanitaria, Instituto de Salud Carlos III, RGDM (G03/212) and the Comunidad de Madrid, Spain. The authors declare that there is no conflict of interest that would prejudice the impartiality of this scientific work.

\section{References}

Alvarez E, Girones N \& Davis RJ 1990 Inhibition of the receptor-mediated endocytosis of diferric transferrin is associated with the covalent modification of the transferrin receptor with palmitic acid. Journal of Biological Chemistry 265 16644-16655.

Alvarez E, Roncero I, Chowen JA, Thorens B \& Blázquez E 1996 Expression of the glucagon-like peptide-1 receptor gene in rat brain. Journal of Neurochemistry 66 920-927.

Barragán JM, Rodriguez R \& Blázquez E 1994 Changes in arterial blood pressure and heart rate induced by glucagon-like peptide-1(7-36)amide in rats. American Journal of Physiology-Endocrinology and Metabolism 266 E459-E466.

Barragán JM, Rodríguez RE, Eng J \& Blázquez E 1996 Interactions of exendin(9-39) with the effects of glucagon-like peptide-1(7-36)amide and of exendin-4 on arterial blood pressure and heart rate in rats. Regulatory Peptides 67 63-68.

Benito E, Blázquez E \& Bosch M 1998 Glucagon-like peptide-1(7-36)amide increases pulmonary surfactant secretion through a cyclic adenosine $3^{\prime}, 5^{\prime}$-monophosphate-dependent protein kinase mechanism in rat type II pneumocytes. Endocrinology 139 2363-2368.

Bouvier M, Loisel TP \& Hebert T 1995a Dynamic regulation of G-protein-coupled receptor palmitoylation: potential role in receptor function. Biochemical Society Transactions 23 577-581.

Bouvier M, Moffett S, Loisel TP, Mouillac B, Hebert T \& Chidiac P 1995 b Palmitoylation of G-protein-coupled receptor: a dynamic modification with functional consequences. Biochemical Society Transactions 23 116-120.

Calvo JC, Gisolfi CV, Blázquez E \& Mora F 1995 Glucagon-like peptide-1(7-36)amide induces the release of aspartic acid and glutamine by the ventromedial hypothalamus of the conscious rat. Brain Research Bulletin 38 435-439.

Cheng Y \& Prusoff WH 1973 Relationship between the inhibition constant $\left(K_{\mathrm{I}}\right)$ and the concentration of inhibitor which causes 50 per cent inhibition $\left(\mathrm{I}_{50}\right)$ of an enzymatic reaction. Biochemical Pharmacology 22 3099-3108.

Chowen JA, Rodriguez de Fonseca F, Alvarez E, Navarro M, García-Segura LM \& Blázquez E 1999 Increased glucagon-like peptide-1 receptor expression in glia after mechanical lesion of the rat brain. Neuropeptides 33 212-215.

Dillon JS, Tanizawa Y, Wheeler MB, Leng X-H, Ligon BB, Rabin DU, Yoo-Warren H, Permutt MA \& Boyd AE III 1993 Cloning and functional expression of the human glucagon-like peptide-1 (GLP-1) receptor. Endocrinology 133 1907-1910.

Goodman OB, Krupnick JG, Santini F, Gurevich W, Penn RB, Gagnon AW, Keen JH \& Benovic JL 1996 -Arrestin acts as a clathrin adaptor in endocytosis of the $\beta_{2}$-adrenergic receptor. Nature $383447-450$.
Gutzwiller JP, Goke B, Drewe J, Hildebrand P, Ketterer S, Handschin D, Winterhalder R, Conen D \& Beglinger C 1999 Glucagon-like peptide-1: a potent regulator of food intake in humans. Gut 44 81-86.

Hawtin SR, Tobin AB, Patel S \& Wheatley M 2001 Palmitoylation of vasopressin V1a receptor reveals different conformational requirements for signaling, agonist-induced receptor phosphorylation and sequestration. Journal of Biological Chemistry 276 38139-38146.

Heuser JE \& Anderson RG 1989 Hypertonic media inhibit receptor-mediated endocytosis by blocking clathrin-coated pit formation. Journal of Cell Biology 108 389-400.

Jensen AA, Pedersen UB, Kiemer A, Din N \& Andersen PH 1995 Functional importance of the carboxyl tail cysteine residues in the human $\mathrm{D}_{1}$ dopamine receptor. Journal of Neurochemistry $\mathbf{6 5}$ $1325-1331$.

Jin SLC, Han VKM, Simmons JG, Towle AC, Lauder JM \& Lund PK 1988 Distribution of glucagon-like peptide-1 (GLP-1), glucagon, and glycentin in the rat brain: an immunocytochemical study. Journal of Comparative Neurology 271 519-532.

Kreymann B, Williams G, Ghatei MA \& Bloom SR 1987 Glucagon-like peptide-1(7-36): a physiological incretin in man. Lancet 2 1300-1304.

Kreymann B, Ghatei MA, Burnet P, Williams G, Kanse S, Diani AR \& Bloom SR 1989 Characterization of glucagon-like peptide-1(7-36)amide in the hypothalamus. Brain Research $\mathbf{5 0 2}$ 325-331.

Moffett S, Mouillac B, Bonin H \& Bouvier M 1993 Altered phosphorylation and desensitization patterns of a human $\beta_{2}$-adrenergic receptor lacking the palmitoylated Cys 341. EMBO Journal 12 349-356.

Moffett S, Adam L, Bonin H, Loisel TP, Bouvier M \& Mouillac B 1996 Palmitoylated cysteine 341 modulates phosphorylation of the $\beta_{2}$-adrenergic receptor by the cAMP-dependent protein kinase. Journal of Biological Chemistry 271 21490-21497.

Moffett S, Rousseau G, Lagacé M \& Bouvier M 2001 The palmitoylation state of the $\beta_{2}$-adrenergic receptor regulates the synergistic action of cyclic AMP-dependent protein kinase and $\beta$-adrenergic receptor kinase involved in its phosphorylation and desensitization. Journal of Neurochemistry 76 269-279.

Mora F, Expósito I, Sanz B \& Blázquez E 1992 Selective release of glutamine and glutamic acid produced by perfusion of GLP-1(7-36)amide in the basal ganglia of the conscious rat. Brain Research Bulletin 29 359-361.

Morello JP \& Bouvier M 1996 Palmitoylation: a post-translational modification that regulates signalling from G-protein-coupled receptor. Biochemistry and Cell Biology 74 449-457.

Navarro M, Rodriguez de Fonseca F, Alvarez E, Chowen JA, Zueco JA, Gómez R, Eng J \& Blázquez E 1996 Colocalization of glucagon-like peptide-1 (GLP-1) receptors, glucose transporter GLUT-2, and glucokinase mRNAs in rat hypothalamic cells: evidence for a role of GLP-1 receptor agonists as an inhibitory signal for food and water intake. Journal of Neurochemistry $\mathbf{6 7}$ 1982-1991.

O’Dowd BF, Hnatowich M, Caron MG, Lefkowitz RJ \& Bouvier M 1989 Palmitoylation of the human $\beta_{2}$-adrenergic receptor. Mutation of Cys341 in the carboxyl tail leads to an uncoupled nonpalmitoylated form of the receptor. Journal of Biological Chemistry $2647564-7569$.

Orskov C, Poulsen SS, Moller M \& Holst JJ 1996 Glucagon-like peptide 1 receptors in the subfornical organ and the area postrema are accessible to circulating glucagon-like peptide 1. Diabetes $\mathbf{4 5}$ 832-835.

Palmer TM \& Stiles GL 2000 Identification of threonine residues controlling the agonist-dependent phosphorylation and desensitization of the rat A3 adenosine receptor. Molecular Pharmacology 57 539-545. 
Perry T, Lahiri DK, Chen D, Zhou J, Shaw KTY, Egan JM \& Greig N 2002 A novel neurotrophic property of glucagon-like peptide 1: a promoter of nerve growth factor-mediated differentiation in PC12 cells. Journal of Phamacology and Experimental Therapeutics $\mathbf{3 0 0}$ 958-966.

Rodriguez de Fonseca F, Navarro M, Alvarez E, Roncero I, Chowen JA, Maestre O, Gómez R, Muñoz RM, Eng J \& Blázquez E 2000 Peripheral versus central effects of glucagon-like peptide- 1 on satiety and body weight loss in Zucker obese rats. Metabolism 49 $1-10$.

Takhar S, Gyomorey S, Su R-C, Mathi SK, Li X \& Wheeler MB 1996 The third cytoplasmic domain of the GLP-1(7-36)amide receptor is required for coupling to the adenylyl cyclase system. Endocrinology 137 2175-2178.

Tang-Christensen M, Larsen PJ, Goke R, Fink-Jensen A, Jessop D, Moller M \& Sheikh SP 1996 Central administration of GLP-1(7-36)amide inhibits food and water intake in rats. American Journal of Physiology-Regulatory, Integrative and Comparative Physiology 271 R848-R856.

Thorens B 1992 Expression cloning of the pancreatic $\beta$ cell receptor for the gluco-incretin hormone glucagon-like peptide 1. PNAS $\mathbf{8 9}$ 8641-8645.

Turton MD, O'Shea D, Gunn I, Beak SA, Edwards CMB, Meeran K, Choi SJ, Taylor GM, Heath MM, Lambert PD, Wilding JPH, Smith DM, Ghatei MA, Herbert J \& Bloom SR 1996 A role for glucagon-like peptide-1 in the central regulation of feeding. Nature 379 69-72.

Vara E, Arias-Díaz J, García C, Balibrea JL \& Blázquez E 2001 Glucagon-like peptide-1(7-36)amide stimulates surfactant secretion in human type II pneumocytes. American Journal of Respiratory and Critical Care Medicine 163 840-846.
Wei Y \& Mojsov S 1995 Tissue-specific expression of the human receptor for glucagon-like peptide-1: brain, heart and pancreatic forms have the same deduced amino acid sequences. FEBS Letters 358 219-224.

Weir GC, Mojsov S, Hendrich GK \& Habener JF 1989 Glucagon-like peptide-1(7-37) actions on endocrine pancreas. Diabetes 38 $338-342$.

Wheeler MB, Lu M, Dillon JS, Leng X-H, Chen C \& Boyd AE III 1993 Functional expression of the rat glucagon-like peptide-1 receptor, evidence for coupling to both adenylyl cyclase and phospholipase C. Endocrinology 133 57-62.

Widmann CH, Dolci W \& Thorens B 1996a Heterologous desensitization of the glucagon-like peptide-1 receptor by phorbol esters requires phosphorylation of the cytoplasmic tail at four different sites. Journal of Biological Chemistry 271 19957-19963.

Widmann CH, Dolci W \& Thorens B $1996 b$ Desensitization and phosphorylation of the glucagon-like peptide-1 GLP-1 receptor by GLP-1 and 4-phorbol 12-myristate-13-acetate. Molecular Endocrinology 10 62-75.

Widmann CH, Dolci W \& Thorens B 1997 Internalization and homologous desensitization of the GLP-1 receptor dependent on phosphorylation of the receptor carboxyl tail at the same three sites. Molecular Endocrinology 11 1094-1102.

Received 22 December 2004

Accepted 27 January 2005

Made available online as an

Accepted Preprint 7 February 2005 